\title{
Prevalence of Depression and its Associated Factors among Male Prisoners at Dillibazar Prison, Kathmandu, Nepal
}

\author{
Kushalata Baral', *Maginsh Dahal², Ganga Khadka³, Anup Adhikari ${ }^{4}$
}

\section{Author Info:}

'Department of Public Health, Nobel College (Pokhara University), Sinamangal, Kathmandu, Nepal

2Department of Public Health, Asian College for Advance Studies, Satdobato, Lalitpur, Nepal

${ }^{3}$ Nutrition and Social Behavior Change Communication Officer, Suaahara Program, NTAG, Dhading, Nepal

${ }^{4}$ Nepal Family Development Foundations, Kupondole, Kathmandu, Nepal

\section{*Corresponding Author:}

Maginsh Dahal, Department of Public Health, Asian College for Advance Studies, Satdobato, Lalitpur, Nepal

Email/Contact: maginsh@gmail.com +977-9841498220

\section{ABSTRACT}

Background: Depression is characterized by persistent low mood, lack of interest and low in energy. We conducted the study to find out the prevalence of depression and its associated factors among male prisoners in Dillibazar prison.

Methods: A cross-sectional analytical design was conducted in 2018 among 195 male prisoners of Dillibazar by using systematic random sampling. The self-administered questionnaire technique was used for data collection along with the standard Major Depression Inventory (MDI) tool of WHO for rating the level of depression. The data were coded and tabulated using Epi-data. The analysis was done by SPSS 16 version. A chisquare test was done for the associations between the variables.

Results: The study revealed that the prevalence of depression among male prisoners at Dillibazar prison was (45.6\%).Among them, (28.2\%) met the criteria of severe depression, (6.7\%) moderate depression, while rest $(10.8 \%)$, of mild depression. It was found that the duration of stay in prison, history of alcoholism, history of smoking, frequency of disputes is not statistically significant with depression. Depression was found a statistically significant association with p-values less than 0.05 at a $5 \%$ level of significance with a history of past illness and a history of drug abuse.

Conclusion: Thus, we can conclude that half of the prisoners are having any kind of depression during their stay in prisoners. Thus this study will be useful in drawing the attention of the authorities towards the value of mental health among prisoners in Nepal

Keywords: Depression, Prisoners, Major Depression Inventory, Nepal

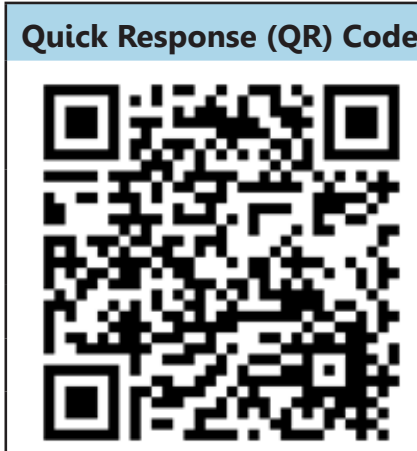

(ג) View PDF

\section{Article Info}

Received: 14 December 2019; Accepted: 18 February 2020; Published Online: 19 February 2020 How to cite this article in Vancouver Style?

Baral K, Dahal M, Khadka G, Adhikari A. Prevalence of depression and its associated factors among male prisoners at Dillibazar prison, Kathmandu, Nepal. Europasian J Med Sci.2020;2(1):30-36. https://doi.org/10.46405/ejms.v2i1.21

Conflict of Interest: None Declared;

Source of Support: Nil

Copyright: (c) 2020 by author(s). This is an open access article distributed under the terms of the Creative Commons Attribution International License 4.0 which permits unrestricted use, distribution, and reproduction in any medium, provided the original work is properly cited.

Scan Me for Full Text

\section{Publisher's Note}

The Europasian Journal of Medical Sciences (EJMS) is an official Journal of Nirvana Psychosocial Care Center \& Research Institute (www. nirvanapscc.com) and published by it. The Journal as well as publisher remain neutral with regards to any jurisdictional claims in any published articles, its contents and the institutional affiliations of the authors. 


\section{INTRODUCTION}

About nine million people are in prison worldwide. ${ }^{1}$ The high levels of morbidity due to psychiatric conditions in inmates has been recorded in many countries, but the rates of mental illness have been increasing over time or either there is a difference in prevalence between low-middle-income countries as compared with high-income ones is still not known. $^{2}$

Depression can be episodic, lifelong or recurrent, impairing an individual's ability to function at work or coping up with daily life. ${ }^{3-5}$ At its chronic form, depression can lead to suicidal tendencies or suicide itself. People having mild depression can be treated without medicines, but people with moderate or severe may need medications and also professional treatments. ${ }^{6}$ Disorders like depression can be diagnosed and treated by non-specialists as a part of primary health care. ${ }^{7}$

Depression leads to the global burden of disease and affects people among all communities throughout the world. ${ }^{8}$ Today, depression is estimated to affect 350 million people. ${ }^{9}$ The World Mental Health Survey conducted in 17 countries found that about 1 in 20 people reported having an episode of depression in the last year on an average..$^{10}$ Depressive disorders commonly start at a young age reducing people's functioning. ${ }^{11}$

Prison health is an inevitable part of public health. ${ }^{12}$ Prisoners doesn't represent a homogeneous segment of society. ${ }^{13}$ Inmates are isolated from society as part of prison life, so depression is most common among them. Overcrowding, dirty and unhygienic living conditions, poor quality of food, inadequate health care, physical or verbal aggression by inmates, lack of purposeful activity, availability of illicit drugs, lack of privacy and time for quiet relaxation and reflection are the factors that aggravate mental morbidity in prisons. And also, feelings of guilt or shame about the offenses they have committed, experience stigma of being been imprisoned, worry about the impact of their behavior on other people, including their families and friends, coupled with anxiety about how much of their former lives will remain intact after releasing are factors that aggravate mental morbidity in prisons..$^{13}$

Depressive symptoms are the most significant cause of morbidity in prisons. Over $90 \%$ of inmates have a mental disorder. ${ }^{14}$ The prison environment and the rules and regulations governing daily life inside prison can be seriously detrimental to mental health. ${ }^{15}$ An estimated 450 million people worldwide suffer from mental or behavioral disorders worldwide. Many of these disorders may be present before entering to prison and can be further exaggerated by the stresses of imprisonment. ${ }^{16}$

Most of the prisons in Nepal were built during the 104 years of Rana rule before 1951 A.D. Out of Nepal's 77districts; there are 74 prisons in 72 districts. In many prisons, the number of inmates is over twice their capacity. Dillibazar prison was established in 1921 A.D. The living conditions and detention facilities of our prison are far from satisfactory but safety standards are awful. An article titled "House of Horrors" shows many prison birds suffer from severe psychological and physical health problems like anxiety, post-traumatic stress, fungal infections and a host of infectious diseases. ${ }^{17}$ Prisoners are the neglected part of Nepalese society as very few studies have been conducted in this issue in our country. Thus, our study aims to find out the prevalence of depression and its associated factors among male prisoners at Dillibazar prison.

\section{MATERIALS AND METHODS}

A cross-sectional study was carried out among 195 male prisoners in the Dillibazar Prison of Nepal. The prison is located centrally in Kathmandu district. It is the oldest adult male correctional facility in the country. Out of the total prisoners after calculating sample size by taking prevalence of 0.85 (Incidence of depression among male prisoners at an urban prison in Pakistan) ${ }^{18}$ and 5\% margin of error 195 samples were taken for the study. We followed the methods of Shrestha et.al 2017 for conducting this study. ${ }^{19}$

The sample size was calculated as follows:

Where, no $=Z^{2} \mathrm{pq} /\left(\mathrm{L}^{2}\right)$

$p=0.85$ (prevalence of depression among male prisoners at an urban jail in Pakistan) $\mathrm{q}=1-0.85$

$\mathrm{Z}=$ is the standard normal variate, which is $1.96 \mathrm{for}$ a $95 \%$ confidence interval.

$\mathrm{L}=$ allowable error $(0.05)$

$\mathrm{N}=$ estimated prisoners of Dillibazar jail (600)

Thus, the sample size was 195

A list of all (600) eligible prisoners was collected from the prison authority to construct a sampling frame for the study which was a systematic random sampling technique was adopted. The name of the male prisoners was written in the list and every third 
prisoner was included in the study (ith interval=total prisoners/total sample size). Prisoners who had spent at least three months in the prison and those who gave informed consent were included in the study.

For collecting data Major Depression Inventory (MDI) tools were used. It is the standard tool of the World Health Organization, to estimate symptom severity. Data were collected using pretested semi-structured questionnaires examining sociodemographic characteristics, detention status, selfreported health problems, substance use status, prisoners' perceived health status and suicidal ideation. The covariates were chosen based upon prior studies. ${ }^{20}$ The questionnaire was translated into local language. The internal consistency of the MDI scale was measured by Cronbach's alpha, which was found to be 0.91 . The pretest was done among 20 prisoners of similar settings.

Data were entered in Microsoft Excel 2007 software and analyzed in the Statistical Package for Social Sciences (SPSS, version 20). The dependent variable was significant depressive symptoms, as assessed by Major Depression Inventory (MDI), the standard tool of WHO for rating the level of depression. The independent variables were sociodemographic characteristics, incarceration profile, substance abuse, suicidal characteristics, healthrelated problems and access to health care.

Descriptive statistics were used to show the prevalence of depression symptoms. A chi-square test was performed to determine the association between depressive symptoms and the independent variables. A p-value of $<0.05$ was considered as the cut-off point for statistical significance.

After the study was approved by Institutional Ethical Review Board, permission to conduct the study in the prison was granted by the Department of Prison Management, Ministry of Home Affairs, Government of Nepal, Written approval to conduct the study in the prison was taken from the Jailer of Dillibazar prison. Informed written consent from the participants was taken before the interview. Prisoners were assured of confidentiality, and they were informed that participation was voluntary and that they could withdraw at any time of the interview without giving reasons for doing so.

\section{RESULTS}

Out of the 195 participants, the higher proportions of the respondents were from 25-34 years of age, i.e. (41.5\%). Regarding the ethnicity, Mongolian (Rai, Magar, Gurung, Tamang, etc.) category represented the highest proportion (24.6\%). Regarding the educational status majority of the respondents (24.1\%) fell in the above higher secondary level of education. Majorities (50.8\%) of the respondents were married whereas (35.4\%) of them reported being engaged in various businesses, before imprisonment. Among total respondents, the mean duration of stay in prison was 42 days (table 1 ).

\begin{tabular}{|l|r|}
\hline \multicolumn{2}{|l|}{ Table 1. Socio-demographic characteristics } \\
\hline Variables & $\mathrm{n}(\%)$ \\
\hline Age, Mean (SD) years & $39.12 \pm 1.29$ \\
\hline Ethnicity & \\
\hline Brahmin & $27(13.8)$ \\
\hline Chettri & $46(23.6)$ \\
\hline Newar & $35(17.9)$ \\
\hline Janjati & $48(24.6)$ \\
\hline Others & $39(20)$ \\
\hline Educational Status & \\
\hline Literate & $47(24.1)$ \\
\hline Primary Education & $35(17.9)$ \\
\hline Lower Secondary Education & $23(11.8)$ \\
\hline Higher Secondary Education & $43(22.1)$ \\
\hline Above higher secondary & $47(24.1)$ \\
\hline Marital status & \\
\hline Unmarried & $82(42.1)$ \\
\hline Married & $99(50.8)$ \\
\hline Divorced & $7(3.6)$ \\
\hline Widow & $7(3.6)$ \\
\hline Previous Occupation & $10(5.1)$ \\
\hline Agriculture & $27(13.8)$ \\
\hline Business & $69(35.4)$ \\
\hline Labor & $30(15.4)$ \\
\hline Government/Organization/Teachers & $18(9.2)$ \\
\hline Duration of stay & $45(23.1)$ \\
\hline Less than 12 months & $45(23.1)$ \\
\hline $12-33$ months & $49(25.1)$ \\
\hline $34-52$ months & $21(10.8)$ \\
\hline $53-72$ months & $16(8.2)$ \\
\hline $73-92$ months & $9(4.6)$ \\
\hline $93-112$ months & 112 months \\
\hline More than 112 \\
Mean =41.7795(42) months
\end{tabular}




\begin{tabular}{|c|c|}
\hline Variables & n (\%) \\
\hline History of illness & $54(27.7)$ \\
\hline \multicolumn{2}{|l|}{ Type of illness(54) multiple choices) } \\
\hline Hypertension & $27(50)$ \\
\hline Tuberculosis & $1(1.9)$ \\
\hline Asthma & $8(14.8)$ \\
\hline Diabetes & $10(18.5)$ \\
\hline Peptic ulcer & $9(16.7)$ \\
\hline Mental illness & $7(12.9)$ \\
\hline Others & $7(12.9)$ \\
\hline $\begin{array}{l}\text { History of medicine intake related to } \\
\text { physical and mental illness }\end{array}$ & $41(21.1)$ \\
\hline History of drinking alcohol & $91(46.7)$ \\
\hline History of smoking & $107(54.9)$ \\
\hline History of drug abuse & $47(24.1)$ \\
\hline \multicolumn{2}{|l|}{ Type of drug used(47) } \\
\hline Marijuana & $36(76.6)$ \\
\hline Illicit IV drugs & $1(2.1)$ \\
\hline Brown sugar & $9(19.1)$ \\
\hline Others & $1(2.1)$ \\
\hline
\end{tabular}

Table 2 represents the proportion of respondents with or without certain habits, their history of chronic illnesses, etc. $27.7 \%$ percent of the respondents reported having the history of past illness whereas. Among the respondent having a past illness, 50\% have hypertension whereas, $21.1 \%$ of respondents had a history of medicine intake related to physical and mental illness. Also, $46.7 \%$ of the respondents had the habit of drinking alcohol, $54.9 \%$ had the habit of smoking, and $24.1 \%$ had the pattern of drug abuse before imprisonment. Among the drug users, $76.6 \%$ said that they use to take marijuana.

Table 3 illustrates the distribution of respondents based on depressive symptoms and their severity. The majority $(69.7 \%)$ of the respondents reported that they never felt "increased appetite" and (63.1\%) reported they never felt "not worth living". However, only $7.2 \%$ of the respondents reported feelings of guilt all the time. Similarly, (39\%) of the respondents reported "low in spirit" some of the time.

Table 4 illustrates the prevalence of depression and its severity. Out of the total respondents, (45.6\%) of the respondents had some sort of depression while remaining (54.4\%) of the respondents did not have the depression. Among the total of (45.6\%) with depression, (28.2\%) of them met the criteria of severe depression, $(6.7 \%)$ of moderate depression while $(10.8 \%)$ met the criteria of mild depression.

Table 5 shows the association of different factors and depression. It shows that the history of drug abuse and history of previous illness was significantly associated with the depression among the male prisoners of Dilli Bazar with a p-value less than 0.05 , while other variables were not significantly associated with our study.

Table 3: Percentage distribution of depression among prisoners based on the Major Depression Inventory

\begin{tabular}{|l|c|c|c|c|c|c|}
\hline Symptoms & $\begin{array}{l}\text { All the } \\
\text { time }\end{array}$ & $\begin{array}{l}\text { Most } \\
\text { of the } \\
\text { time }\end{array}$ & $\begin{array}{l}\text { More than } \\
\text { half the } \\
\text { time }\end{array}$ & $\begin{array}{l}\text { Less than } \\
\text { half the } \\
\text { time }\end{array}$ & Sometimes & Never \\
\hline Low in spirit & 27.7 & 17.4 & 9.2 & 1.5 & 39 & 5.1 \\
\hline Loss of interests in daily activities & 15.9 & 19 & 8.7 & 5.6 & 28.2 & 22.6 \\
\hline Lack of energy & 14.4 & 21 & 8.2 & 3.1 & 27.7 & 25.6 \\
\hline Less self-confident & 13.8 & 16.4 & 5.6 & 6.2 & 12.8 & 45.2 \\
\hline Feelings of guilt & 7.2 & 14.4 & 2.6 & 2.6 & 30.3 & 43.1 \\
\hline Not worth of living & 4.1 & 4.6 & 3.1 & 1 & 24.1 & 63.1 \\
\hline Difficulty in concentration & 13.3 & 15.4 & 3.1 & 4.6 & 26.2 & 37.4 \\
\hline Very restless & 19.5 & 15.9 & 5.1 & 2.6 & 36.4 & 20.5 \\
\hline Slowed down & 13.3 & 12.8 & 5.6 & 3.6 & 27.7 & 36.9 \\
\hline Sleeping trouble & 19.5 & 16.9 & 3.6 & 5.1 & 30.8 & 24.1 \\
\hline Reduced appetite & 9.7 & 14.4 & 2.1 & 5.6 & 37.4 & 30.8 \\
\hline Increased appetite & 4.1 & 2.6 & 1.5 & 1 & 21 & 69.7 \\
\hline
\end{tabular}


Table 4: Score obtained for the prevalence of Depression and Severity

\begin{tabular}{|l|l|l|}
\hline Score & Frequency $(\%)$ & Result \\
\hline$<20$ & $106(54.4 \%)$ & No depression(Normal) \\
\hline $20-24$ & $21(10.8 \%)$ & Mild depression \\
\hline $25-30$ & $13(6.7 \%)$ & Moderate depression \\
\hline 30 or above & $55(28.2 \%)$ & Severe depression \\
\hline
\end{tabular}

Table 5: Association between various factors and Depression

\begin{tabular}{|c|c|c|c|c|c|c|c|}
\hline \multirow[t]{2}{*}{ Variables } & \multirow[t]{2}{*}{ Categories } & \multicolumn{4}{|c|}{ Status of Depression } & \multirow[t]{2}{*}{$\chi^{2}(\mathrm{df})$} & \multirow[t]{2}{*}{ P-value } \\
\hline & & \multicolumn{2}{|c|}{ Normal (\%) } & \multicolumn{2}{|c|}{ Depressed (\%) } & & \\
\hline \multirow{2}{*}{$\begin{array}{l}\text { Duration } \\
\text { of stay(month) }\end{array}$} & $\leq$ mean score & \multicolumn{2}{|l|}{$61(31.3)$} & \multicolumn{2}{|l|}{ 61(31.3) } & \multirow[t]{2}{*}{$2.496(1)$} & \multirow[t]{2}{*}{0.143} \\
\hline & $\geq$ mean score & \multicolumn{2}{|l|}{$28(14.4)$} & \multicolumn{2}{|l|}{$45(23.1)$} & & \\
\hline \multirow{2}{*}{$\begin{array}{l}\text { History of past } \\
\text { illness }\end{array}$} & Yes & \multirow{2}{*}{\multicolumn{2}{|c|}{$\begin{array}{l}20(10.3) \\
86(44.1)\end{array}$}} & \multirow{2}{*}{\multicolumn{2}{|c|}{$\begin{array}{l}34(17.4) \\
55(28.2)\end{array}$}} & \multirow[t]{2}{*}{$9.032(1)$} & \multirow[t]{2}{*}{$0.003^{*}$} \\
\hline & No & & & & & & \\
\hline \multirow{2}{*}{$\begin{array}{l}\text { History of } \\
\text { alcoholism }\end{array}$} & Yes & \multicolumn{2}{|l|}{$44(22.6)$} & \multicolumn{2}{|l|}{$47(24.1)$} & \multirow[t]{2}{*}{$2.482(1)$} & \multirow[t]{2}{*}{0.115} \\
\hline & No & \multicolumn{2}{|l|}{$62(31.8)$} & \multicolumn{2}{|l|}{$42(21.5)$} & & \\
\hline \multirow{2}{*}{$\begin{array}{l}\text { History of } \\
\text { smoking }\end{array}$} & Yes & \multicolumn{2}{|l|}{$54(27.7)$} & \multicolumn{2}{|l|}{$53(27.2)$} & \multirow[t]{2}{*}{$1.447(1)$} & \multirow[t]{2}{*}{0.229} \\
\hline & No & \multicolumn{2}{|l|}{$52(26.7)$} & \multicolumn{2}{|l|}{$36(18.5)$} & & \\
\hline \multirow{2}{*}{$\begin{array}{l}\text { History of drug } \\
\text { abuse }\end{array}$} & Yes & \multicolumn{2}{|l|}{$18(9.2)$} & 29(14.9) & & 6.439 & $0.011^{*}$ \\
\hline & No & $88(45.1)$ & & $60(30.8)$ & & & \\
\hline Social factors & Most of the time & $6(3.1)$ & & $7(3.6)$ & & $1.07(1)$ & 0.585 \\
\hline $\begin{array}{l}\text { (frequency of } \\
\text { disputes) }\end{array}$ & $\begin{array}{l}\text { Some of the } \\
\text { time }\end{array}$ & 61(31.3) & & $45(23.1)$ & & & \\
\hline & Never & $39(20)$ & & $37(19)$ & & & \\
\hline Variables & Categories & & sfied & Dis & atisfied & $\chi^{2}(\mathrm{df})$ & $p$-value \\
\hline & & Normal & Depressed & Normal & Depressed & & \\
\hline Physical Factors & living space & $29(14.4)$ & $18(9.2)$ & $77(39.5)$ & 71(36.4) & $3.348(3)$ & 0.246 \\
\hline & $\begin{array}{l}\text { recreation } \\
\text { environment }\end{array}$ & $22(11.3)$ & $8(4.1)$ & $84(43.1)$ & $81(41.5)$ & $1.453(3)$ & 0.023 \\
\hline & $\begin{array}{l}\text { learning } \\
\text { environment }\end{array}$ & $9(4.6)$ & $7(3.6)$ & $97(49.7)$ & $82(42.1)$ & $5.347(3)$ & 0.875 \\
\hline & $\begin{array}{l}\text { drinking water } \\
\text { facility }\end{array}$ & $51(26.2)$ & $42(21.5)$ & $55(28.2)$ & $47(24.1)$ & $2.105(3)$ & 0.898 \\
\hline
\end{tabular}

\section{DISCUSSION}

As followed the scoring instructions of MDI, the overall findings revealed that the prevalence of depressive symptoms at Dillibazar prison is (45.6\%). Among them, (28.2\%) of them met the criteria of severe depression, (6.7\%) of moderate depression while rest $(10.8 \%)$, met the criteria of mild depression. A study was done among the inmates in the regional prison of eastern Nepal on 2017 revealed that $35.3 \%$ of the inmates had symptoms of depression, which is slightly less than our study. ${ }^{19}$ The incidence of depression was even higher among male prisoners in some other countries. At male prisoners at District Prison
Lahore, Pakistan out of the 100 male prisoners, 85 (85\%) were found to be suffering from depression. However, in a similar study among Michigan, USA male prisoners, the incidence was (20.1\%) which is lower than that of Nepali and Pakistani male prisoners. The possibility for this comparatively low incidence may be a better prison environment in Michigan and a better health care system inside the prison. ${ }^{18,21}$

The significant proportion of the male with depression met the criteria for severe depression (28.2\%). The age group (25-34 years) male, (19.1\%) who can read and write their name only and (22.47\%) 
with secondary level education were mainly affected. Unlike the prisoners of Sao Paulo, Brazil, the finding revealed that men with good economic background were mostly affected. Married men (58.42\%) were found to be mainly affected. Fiftyfive percent of the respondents answered positively when asked about the history of smoking. Among those respondents who had the habit of smoking majority of them fell in the age group 25-34 years. In the current study, it showed that there was no association between the habit of smoking in the past and depression.22, 23 This may be because of irregular smoking or maybe they quit smoking long ago.

Similarly, the history of alcoholism was also the highest $(36.26 \%)$ in the middle age group (25$34 \mathrm{yrs})$. When inquired about the previous habit of drug abuse only (24.1\%) of the respondents gave positive history, and the majority (38.29\%) of them fell in the age group 25-34 years and (34.04\%) of them fall in the age group 16-24 years. In contrary to other similar research, this investigation does show a statistically significant correlation between the history of drug abuse and the occurrence of depression. Many investigations in similar settings have proved that the history of substance abuse has been attributed to a range of psychological disorders. ${ }^{24,25}$ In this study, significant association (P-value 0.03 ) was found between the history of past illness among the respondents and depression.

When it came to the status of imprisonment, the majority $(73.8 \%)$ of the respondents were sentenced while (26.2\%) were on remand. However, the imprisonment status did not affect the outcome of depression (P-value 0.573 ). From many investigations, it has been inferred that the occurrence of mental illness is more on remanded prisoners than those sentenced. Many other similar studies have claimed that remand prison populations tend to have even greater mental health problems than sentenced populations. Because it has been suggested that maybe the remands are intensely involved in the court process or experiencing the first shock of incarceration, are unknown to the prison authorities, are separated from their normal lives and maybe withdrawing from drugs or abuse. ${ }^{26,27}$

In this study overcrowding and suffocation has been more pronounced (51.8\%), while existing facility of toilets, drinking water, water for other purposes, environment for the recreation, learning skills was reported satisfactorily by the majority of the respondents. The physical factors have been operationalized by probing into the provided living space, experiencing suffocation or congestion, environment for recreation, environment for learning and training skills, facility of drinking water or for other purposes, existing facility of the toilets. Since the "p-value" for "environment for recreation" is 0.023 which is less than 0.05 , the null hypothesis is rejected, and there is sufficient statistical evidence to infer that the recreational environment determines the occurrence of depression for recreation at (5\%) level of significance.

On probation, (75.9\%), i.e., the majority of the respondents reported being dissatisfied with the provided living space while (24.1\%) reported being satisfied. While analyzing the obtained responses for inferring the co-relationship between the depression and the physical and social environment Chi-square test was used. Since, the significant value ( $p$-value) inferred through Chi-square test for both the provided living space and experiencing suffocation or congestion is 0.246 , which is more than 0.05 , the null hypothesis is accepted and there is no statistical evidence to infer that the living space determined the occurrence of depression and experiencing suffocation or congestion at $5 \%$ level of significance.

This study has certain limitations but has been able to throw some light about the prevalence of depressive symptoms and associated factors among the male prisoners in the Dillibazar prison of Kathmandu district.

\section{CONCLUSION}

Thus, we can conclude that a history of past illness and a history of drug abuse was significantly associated with the depression among the prisoners of Dillibazar prison, Nepal. We can also conclude that an MDI tool is the best option to access the status of depression among prisoners.

\section{REFERENCES}

1. Fazel S, Danesh J. Serious mental disorder in 23000 prisoners: a systematic review of 62 surveys. Lancet. 2002; 359: 545-50. https://doi.org/10.1016/S01406736(02)07740-1 Google Scholar | CrossRef | Full Text

2. Fazel S, Seewald K. Severe mental illness in 33,588 prisoners worldwide: a systematic review and meta- 
regression analysis. Br J Psychiatry. 2012; 200: $364-$ 73. $\quad$ https://doi.org/10.1192/bjp.bp.111.096370 Google Scholar | CrossRef | Full Text

3. World Health Organization. Depression: definition. World Health Organization, 2015. Google Scholar | PubMed | Full Text

4. Anon. WHO Resource Book on Mental Health, Human Rights and Legislation. Chinese Medical Journal: English Edition. 2005: 988

5. Chwastiak LA, Von KM. Disability in depression and back pain: evaluation of the World Health Organization Disability Assessment Schedule (WHO DAS II) in a primary care setting. Journal of Clinical Epidemiology. 2003; 56: 507-14. https://doi.org/10.1016/S0895-4356(03)00051-9 CrossRef | Full Text

6. Janov A. The Mystery Known as Depression.Activitas Nervosa Superior. 2013; 55: 79-107. https://doi. org/10.1007/BF03379599 [CrossRef | Full Text

7. Armiya'U AY, Audu MD, Obembe A, Adole O and Umar MU. A study of psychiatry morbidity and co-morbid physical illness among convicted and awaiting trial inmates in Jos prison. Journal of Forensic \& Legal Medicine. 2013; 20: 104851.https://doi.org/10.1016/j.jflm.2013.08.002 [CrossRef | Full Text

8. Gussak D. Comparing the effectiveness of art therapy on depression and locus of control of male and female inmates. Arts in Psychotherapy. 2009; 36: 202-7. https://doi.org/10.1016/j.aip.2009.02.004 CrossRef | Full Text

9. Worley H. Depression a leading contributor to global burden of disease. Washington Population Reference Bureau. 2014.

10. Reddy MS. Depression: the disorder and the burden. Indian Journal of Psychological Medicine. 2010; 32: 1. https://doi.org/10.4103/0253-7176.70510

11. Marcus $M$, Yasamy $M T$, Ommeren $M v$, Dan Chisholm and Saxena S. DEPRESSION A Global Public Health Concern. WHO Department of Mental Health and Substance Abuse, 2012. https://doi.org/10.1037/e517532013-004 CrossRef $\mid$ Full Text

12. Smith $R$, . The mental health of prisoners. IHow many mentally abnormal prisoners? British Medical Journal. 1984; 288: 308-10. https://doi.org/10.1136/bmj.288.6413.308 CrossRef | Full Text

13. Baumann M, Meyers R, Bihan EL and Houssemand C. Mental health (GHQ12; CES-D) and attitudes towards the value of work among inmates of a semi-open prison and the long-term unemployed in Luxembourg. Bmc Public Health. 2008; 8: 1-10. $\quad$ https://doi.org/10.1186/1471-2458-8-214 PubMed | CrossRef | Full Text

14. Sergio Baxter A, Maíra Mendes DS, Maria Ines $Q$, et al. Prevalence of mental disorders among prisoners in the state of Sao Paulo, Brazil. Plos One 2014; 9: e88836. https://doi.org/10.1371/journal. pone.0088836 [CrossRef] | Full Text

15. Birmingham L. The mental health of prisoners. Advances in psychiatric treatment. 2003; 9: 191-9. CrossRef | Full Text https://doi.org/10.1192/apt.9.3.191

16. World Health Organization. Mental health and prisons. Mental Health, Human rights and Legislation Information Sheet, . 2007

17. Hari Bansh Jha. House of horrors. Republica. Kathmandu 17 Jun 2015.

18. Shahid I, Aftab A, Yousaf $Z$, Haider Naqvi $S$ and Hashmi A. Prevalence of Depression among Male Prisoners at an Urban Jail in Pakistan. 2014, p.699.

19. Shrestha G, Yadav DK, Sapkota N, et al. Depression among inmates in a regional prison of eastern Nepal: a cross-sectional study. BMC Psychiatry. 2017; 17: 348. https://doi.org/10.1186/s12888-017-15149 [CrossRef | Full Text

20. Nobile CG, Flotta D, Nicotera G, Pileggi C and Angelillo IF. Self-reported health status and access to health services in a sample of prisoners in Italy. BMC Public Health. 2011; 11: 529. https://doi. org/10.1186/1471-2458-11-529 [CrossRef | Full Text

21. Fries $B E$, Schmorrow $A$, Lang $S W$, et al. Symptoms and treatment of mental illness among prisoners: A study of Michigan state prisons. International Journal of Law \& Psychiatry. 2013; 36: 31625. $\quad$ https://doi.org/10.1016/j.ijlp.2013.04.008 [CrossRef | Full Text

22. Andreoli SB, Dos Santos MM, Quintana MI, et al. Prevalence of mental disorders among prisoners in the state of Sao Paulo, Brazil. PloS one. 2014 9: e88836-e. https://doi.org/10.1371/journal. pone.0088836 [CrossRef | Full Text

23. Rahmah A, Blogg J, Silitonga N, Aman M and Michael PR. The health of female prisoners in Indonesia. International Journal of Prisoner Health. 2014; 10 : 252. https://doi.org/10.1108/IJPH-08-2013-0038 [CrossRef | Full Text

24. Yener U, Mehmet $Y$, Nuran B, Nazan B. Prevalence of depression, anxiety, stress, and anger in Turkish prisoners. Journal of Forensic Sciences. 2013; 58: 1210-8. https://doi.org/10.1111/1556-4029.12142 [CrossRef | Full Text

25. Assadi SM, Noroozian M, Pakravannejad $M$, et al. Psychiatric morbidity among sentenced prisoners: prevalence study in Iran. $\mathrm{Br} J$ Psychiatry. 2006; 188: 159-64. https://doi.org/10.1192/bjp.188.2.159 [CrossRef | Full Text

26. Falissard B, Loze JY, Gasquet I, et al. Prevalence of mental disorders in French prisons for men. Bmc Psychiatry. 2006; 6: 1-6. https://doi. org/10.1186/1471-244X-6-33 [PubMed | CrossRef Full Text

27. Davidson $M$, Humphreys MS, Johnstone EC and Owens DG. Prevalence of psychiatric morbidity among remand prisoners in Scotland. Br J Psychiatry. 1995: 167: 545-8. https://doi.org/10.1192/ bjp.167.4.545 [CrossRef | Full Text 